\title{
Effect of substrate on periphyton communities and relationships among food web components in shallow hypertrophic lake
}

\author{
Monika TARKOWSKA-KUKURYK, ${ }^{*}$ Tomasz MIECZAN \\ Department of Hydrobiology, University of Life Sciences, Dobrzańskiego 37, 20-262 Lublin, Poland \\ *Corresponding author: monika.kukuryk@up.lublin.pl
}

\begin{abstract}
We studied the role of natural (common reed) and artificial substrata (bamboo) in structuring the abundance and taxonomic composition of periphyton assemblages. Investigations were conducted in a shallow, hypertrophic lake situated in the area of Polesie Lubelskie (Eastern Poland). Periphyton communities (algae, ciliates, small metazoa and chironomids) on both types of substratum were sampled monthly, from May to November of 2007. Water samples for chemical analysis were collected together with biological samples. We selected the group of ten environmental variables which are the most important in determining the habitat conditions in highly eutrophic lakes: temperature, Secchi disc visibility, conductivity, dissolved oxygen, periphytic chlorophyll-a, $\mathrm{N}-\mathrm{NO}_{3}, \mathrm{~N}-\mathrm{NH} \mathrm{H}_{4}, \mathrm{TP}^{\mathrm{P}} \mathrm{P}-\mathrm{PO} \mathrm{O}_{4}$ and total organic carbon (TOC). The abundances of periphytic algae, ciliates, metazoa and chironomids were significantly affected by season and substrate. On natural substrata, in all studied months, periphyton communities showed higher abundances. The results of PCA analysis confirmed the distinction between periphyton communities on natural and artificial substrata. The Monte Carlo permutation test showed that the periphyton communities on common reed were the most significantly affected by temperature, $N$ - $N O_{3}$, Secchi disc visibility and TOC. The communities on artificial substrata were significantly influenced by temperature, $P$-PO $\mathrm{O}_{4}$ and TOC. On natural substrata biomass of periphytic algae was significantly negatively correlated with abundances of all groups of potential grazers (ciliates, metazoa, chironomids). On artificial substrata the relations between components of periphytic food web were stronger; correlation coefficients between algae, protists and chironomids were significant at $P<0.01$. The results of analysis indicate that periphytic algae can play an important role as food source for higher trophic levels. These interactions are less significant on natural (reed) substrata, where algae during their growth may use nutrients releasing by plants. On inert substrata intensive feeding activity of grazers (ciliates, metazoan, chironomids) can markedly reduce algal biomass and affect their taxonomic composition.
\end{abstract}

Key words: periphyton communities, artificial substrata, common reed, hypertrophic lake.

Received: January 2012. Accepted: May 2012.

\section{INTRODUCTION}

Shallow lakes, especially the small ones with extensive littoral area, have a high potential for periphyton growth (Wetzel, 1990). In such ecosystems periphyton develops on a wide range of submerged substrata, including macrophyte tissues (Vermaat, 2005). Periphyton assemblage associated with macrophytes is a complex structure with algae, protozoa, small metazoan, as well as macroinvertebrates. In general, both the structure and abundance of periphyton communities are affected by the available resources (nutrients, light) and predation by higher trophic levels (grazing) (Rosemond et al., 1993; Liboriussen et al., 2005). Another factor having an effect on periphyton is substrate specificity. Most studies stress the role of substrate in habitats of low nutrient availability because macrophytes may represent a substantial nutrient source, as they release nutrients (Riber et al., 1983; Moeller et al., 1988). In eutrophic lakes, where nutrient availability is high, the differences observed between inert and living substrates are not striking (Fairchild and Everett, 1988; Hillebrand and Sommer, 2000). On the other hand, studies by Kahlert and Pettersson (2002) showed that internal processes in the algal mat may regulate structure of periphytic algae more intensively than lake trophy.

We tested the effect of substrate on the structure of periphyton food web (Fig. 1) in highly eutrophic lake. In hypertrophic lakes, high nutrient loading often causes substantial reduction in submerged macrophytes and an intensive development of rush vegetation. Deterioration of environmental conditions leads to a decrease in the colonization area and diversity for communities associated with macrophytes (Scheffer et al., 1993; Declerck et al., 2005; Gonzalez-Sagrario et al., 2005). However, studies which have been undertaken to describe the composition of algae as well heterotrophic components of periphyton are very scarce and hardly sufficient. Up to now most studies of natural and inert substrata concerned periphytic algae (Moschini-Carlos et al., 2000; Kiss et al., 2003; Lane et al., 2003; Kralj et al., 2006), while little work has been done to identify higher trophic levels of periphyton in lentic environments, such as ciliates (Mieczan, 2006; Henglong et al., 2009), small metazoa (Sakuma et al., 2004; Atilla et al., 2005) and chironomid larvae (Francis and Kane, 1995; Chaloner and Wotton, 1996). 
Different artificial substrata have been used to study their effect on periphyton communities. Glass slides are frequently used in algae and ciliates studies (Kaur and Mehra, 1998; Danilov and Ekelund, 2001; Albay and Akcaalan, 2003; Lane et al., 2003). Ceramic tile substrates and plastic artificial plants are introduced for colonization of small metazoa and macroinvertebrates (Benoit et al., 1998; Taniguchi et al., 2003). In the present study, periphyton communities were identified on an artificial bamboo substratum. Such a substratum was previously used by Azim et al. (2002) to study the structure of heterotrophic components of periphyton (rotifers, crustaceans, oligochaetes and chironomids larvae) in aquaculture ponds. In the studied lake, the selection of the type of artificial substrata was closely related to the structure of vegetation. The lake is shallow and hypertrophic, surrounded by a dense, wide belt of emergent vegetation dominated by common reed (Phragmites australis (Cav.) Trin. ex Steud). Bamboo shoots show a high morphological similarity to reed stems and can be sited at the same habitat conditions (depth, orientation, light condition, water level) as plants.

The general hypotheses were: i) under hypertrophic conditions, where colonization area for communities associated with macrophytes is markedly reduced, the use of artificial bamboo substrata may increase colonization surface and enhance the growth of periphyton communities; ii) in hypertrophic lake, the biomass of periphytic algae on artificial substrata is determined by high nutrients concentration. The use of artificial substrata eliminates biological interactions between algae and host plant (Reid et al., 1995; Lane et al., 2003). Macrophyte tissues release biologically active chemicals which may influence algal growth (Gross et al., 1996; Jones et al., 2000); iii) the structure and biomass of periphytic algae associated with artificial substrata are structured by the grazing pressure of higher trophic lev-

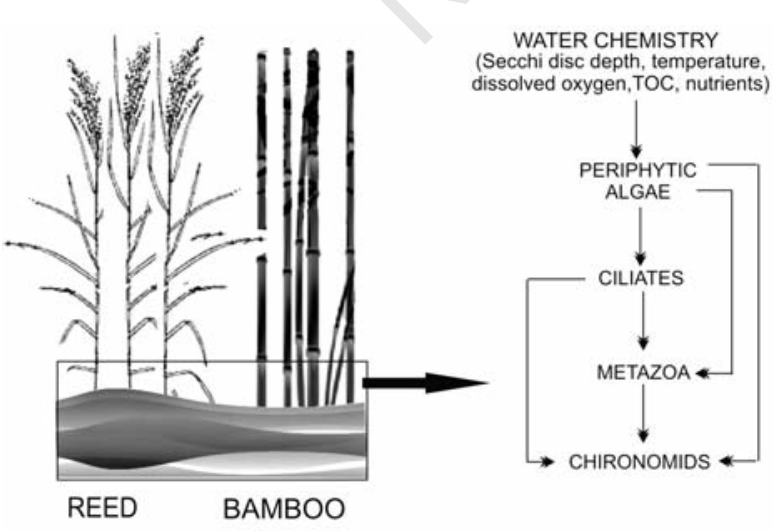

Fig. 1. Scheme of relations between components of periphyton communities on natural (reed) and artificial (bamboo) substrates. Arrows indicate the way of relations between periphyton communities. els. Invertebrate grazers may show preferential feeding, grazed mostly on highly edible and nutritious algae and keep periphyton biomass low (Jones et al., 1998; Jones and Sayer, 2003); iv) the taxonomic composition and abundance of invertebrate grazers are influenced by substrate type and food (algae biomass and availability).

The specific goals of the study were: i) to analyze the taxonomic composition and abundance of periphytic algae, ciliates, metazoa and chironomids on natural (reed) and artificial (bamboo) substrata; ii) to describe environmental variables responsible for the distribution of algae and invertebrates on natural and artificial substrata; iii) to evaluate the influence of a particular substratum on the interactions between components of the periphytic food web.

\section{METHODS}

\section{Study area}

Lake Syczyńskie $\left(51^{\circ} 17^{\prime} \mathrm{N}\right.$ and $\left.23^{\circ} 14^{\prime} \mathrm{E}\right)$ is a small and shallow (surface area 5.9 ha, max depth $2.9 \mathrm{~m}$ ) hypertrophic lake situated in the area of Polesie Lubelskie (Eastern Poland) (Fig. 2). Over $80 \%$ of the lake catchment is used for agriculture purpose (mostly arable lands and meadows). The lake is characterized by permanent and long lasting blooms of cyanophyte. Emergent vegetation is well developed (mean cover amounted to $24 \%$ of lake surface area), dominated by common reed (Phragmites australis (Cav.) Trin. ex Steud.) and three accompanying species: bulrush (Schoenoplectus lacustris (L.) Palla), broadleaf cattail (Typha latifolia L.) and sweet flag (Acorus calamus L.). Submerged vegetation is limited to very small, single stands of rigid hornwort (Ceratophyllum demersum L.) and sago pondweed (Potamogeton pectinatus L.).

\section{Water sampling}

Water for chemical analysis were taken monthly from May to November 2007, simultaneously with periphyton samples. Samples were collected $30 \mathrm{~cm}$ under the water surface. Three water samples were collected each month. Temperature, conductivity and dissolved oxygen were recorded in situ using YSI 556 MPS electrode. Concentrations of total organic carbon (TOC) were measured using Portable Multi Parameter Analyser of water quality, PASTEL UV (SECOMAM). Water for analysis of nutrients and chlorophyll-a concentration was filtered onto GF/C filters. Chlorophyll-a was extracted overnight in $90 \%$ acetone and measured with a spectrophotometer (Golterman, 1969). Concentrations of total phosphorous (TP) and dissolved orthophosphates $\left(\mathrm{P}^{-} \mathrm{PO}_{4}\right)$ were determined using spectrophotometric method with ammonium heptamolybdate; concentrations of $\mathrm{N}^{-\mathrm{NH}_{4}}$ were determined with Nessler's method and concentrations of $\mathrm{N}^{-\mathrm{NO}_{3}}$ using colorimetric method with brucine (Hermanowicz et al., 1999). 


\section{Periphyton communities sampling}

The periphyton communities were sampled from natural (common reed) and artificial substrata (bamboo) at a depth of 0.5-1 $\mathrm{m}$ in littoral zone. Artificial substrata were placed inside reed bed, after the decrease of ice cover (at the end of March). Number of bamboo shoots introduced to the lake was similar to density of reed beds. Sampling was done on a monthly basis from May to November 2007. During each sampling occasion 6 periphyton samples were collected from each substratum type.

Samples of periphytic algae were taken as a scrapings with a quadrant of $2 \times 2 \mathrm{~cm}^{2}$ (one scraping per one reed or bamboo stem) using sharp edged scalpel and soft toothbrush. Stems were collected very gently to minimize the loss of organisms during stem retrieval from the lake. Scrapings were done just after the stems were pulled from the water. Each scraping was gently put into a separate plastic bottle filled with $300 \mathrm{~mL}$ of distilled water and mixed. Next the suspension was filtered through a $250 \mu \mathrm{m}$ mesh size to avoid contamination of small plant fragments or occasional invertebrates. Then, a $100-\mathrm{mL}$ subsample was fixed with Lugol's liquid and by formaldehyde with glycerin solution and used for algae identification. From the subsample was taken $2 \mathrm{~mL}$ of aliquot and put on a glass slide with counting chamber. Each slide was than examined at 400× magnification. At least 200 algal cells were counted and classified to the genus level. The counts were based on cells and also for filaments (each filament of the length of $100 \mu \mathrm{m}$ was counted as one cell). The algae identifications were based on Van den Hoek et al. (1995). Biomass of periphytic algae was calculated using the lengths and widths of algal cells and common geometric equations (Rott, 1981) and expressed in $\mathrm{mg} \mathrm{m}^{-2}$ of reed (bamboo) surface. Relative abundances of taxonomic group of algae were estimated in total biomass of algae based on biomass of counted cells and filaments.

In order to determine the density of ciliates and small metazoan one sample consisted of $10 \mathrm{~cm}^{-2}$ of periphyton taken from the reed stems and bamboo by means of a scalpel. Samples were fixed with Lugol's solution ( $1 \% \mathrm{v} / \mathrm{v})$ and settled for at least $24 \mathrm{~h}$ in plankton chambers. The ciliates and metazoan (rotifers, cladocerans and copepods) were counted and identified with an inverted microscope at magnification $\times 400-1000$. Ciliates are highly perishable, and their type of motility is a species specific feature; for this reason, species determination and measurements were carried out on live material immediately after return to the laboratory and after silver impregnation (Augustin et al., 1984). Taxonomic identification was based primarily on Foissner and Berger (1996), Foissner et al. (1999).

Chironomids were collected by an Epi-Korn apparatus (Kornijów and Kairesalo, 1994). The apparatus consists of a perspex tube and a circular sieve (mesh size $250 \mu \mathrm{m}$ ). One sample consisted of one stem (reed or bamboo). Field samples were transported to the laboratory, where the larvae of midges were removed from reed and bamboo stems and preserved in 4\% formaldehyde solution, counted and identified. The nomenclature of Chironomidae larvae followed Wiederholm (1983). Lengths and diameters of reed and bamboo shoots collected in samples were measured in order to calculate density of midges per $\mathrm{m}^{2}$ of reed (bamboo) surface.

\section{Data processing}

Mean densities of the different groups of periphytic organisms were compared between natural and artificial sub-

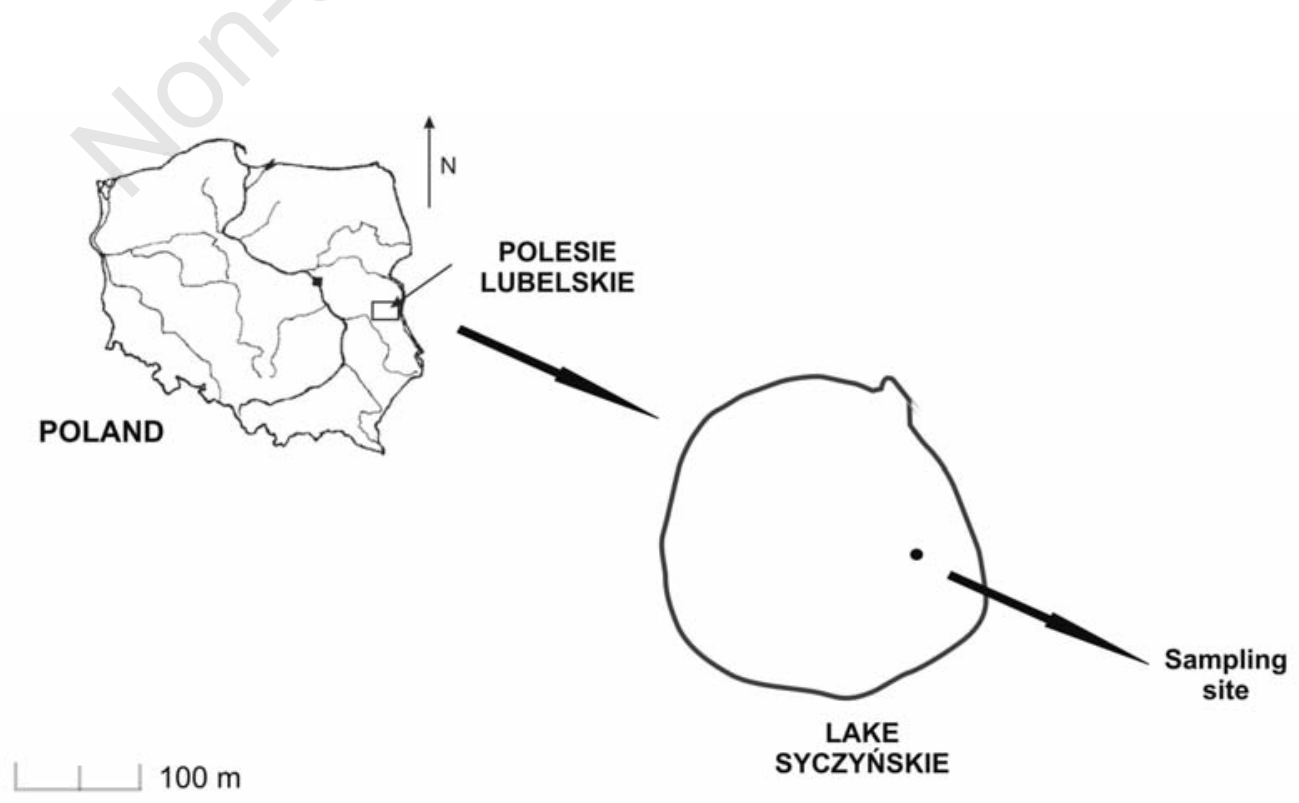

Fig. 2. Location of studied lake Syczyńskie. 
strata and between months using two-way repeated measures ANOVA (substratum, time). Pearson's correlation coefficients were calculated in order to specify the interactions between components of periphytic food web. The analysis was performed using STATISTICA 7.0 software.

Ordination techniques were used to describe the relationships between the abundance of taxonomic groups (algae, ciliates, metazoan, chironomids) of periphytic organisms on natural (reed) and artificial (bamboo) substrata and environmental variables. An indirect multivariate method, DCA, was used to measure and illustrate gradients indicated by periphyton communities. Because the length of the gradient was $<3$ standard deviations, redundancy analysis (RDA) was used to explore the relationships between the abundance of taxonomic groups and physical and chemical variables (ter Braak and Šmilauer, 2002). The RDA method relates numerical character of analyzed data (Jongman et al., 1987). Automatic forward selection of environmental variables, Monte Carlo permutation test (999 permutations) was used to determine the most important variables (Lepš and Šmilauer, 2003). Variables which level of significance exceeded 0.05 were marked passively on the diagrams. The principal component analysis (PCA) was performed in order to confirm the separation of periphyton communities on natural and artificial substrata. The ordination analyses were performed by means of CANOCO 4.5 for Windows.

\section{RESULTS}

\section{Physical and chemical water parameters}

Physical and chemical water parameters showed visible seasonal variability (Tab. 1). Observed values were typical for hypertrophic lakes. Secchi disc visibility was very low and ranged for $0.27 \mathrm{~m}$ (November) to $0.80 \mathrm{~m}$ (June). Planktonic chlorophyll- $a$, as an indicator of planktonic algae biomass, ranged from 11.90 (May) to $40.94 \mu \mathrm{g}$ $\mathrm{L}^{-1}$ (October). Concentrations of total phosphorous were high during the whole study ranging from $76 \mu \mathrm{g} \mathrm{L}^{-1}$ in November to $321 \mu \mathrm{g} \mathrm{L}^{-1}$ in July. Concentrations of dissolved oxygen always exceeded $9.0 \mathrm{mg} \mathrm{L}^{-1}$.

\section{Periphytic algae}

The biomass of periphytic algae $\left(\mathrm{mg} \mathrm{m}^{-2}\right)$ showed visible seasonal variability (Fig. 3 A,B). Observed seasonal differences were significant on both natural (ANOVA; $\mathrm{F}=7.86 ; \mathrm{P}<0.001$ ) and artificial (ANOVA; $\mathrm{F}=15.95 ; \mathrm{P}<0.001)$ substrata. Total algal biomass on natural substrata showed significantly higher values (ANOVA; $\mathrm{F}=151.81 ; \mathrm{P}<0.001$ ) than on artificial ones. On both substrata three taxonomic groups of algae were identified: cyanophyte, diatoms and chlorophytes. On natural and artificial substrata the highest algal biomass was observed in July, $56.79 \mathrm{mg} \mathrm{m}^{-2}$ and $48.26 \mathrm{mg} \mathrm{m}^{-2}$, respectively. The lowest values were noted in November, $4.28 \mathrm{mg} \mathrm{m}^{-2}$ on natural substrata and $3.56 \mathrm{mg} \mathrm{m}^{-2}$ on artificial substrata. Cyanophyte were the dominant group on both substrata. The proportions of these algae varied from $44 \%$ (July, November) to $49 \%$ (June) on natural substrata and from $43 \%$ (June) to $51 \%$ (September, October) on artificial substrata. Domination structure of cyanophyte changed during the studied period: in May and June dominated Microcystis sp.; Calothrix sp. in August and September; whereas in July, October and November, Oscillatoria sp. prevailed.

\section{Ciliates}

ANOVA indicated that ciliates abundances were significantly affected by time on both natural $(\mathrm{F}=27.83$; $\mathrm{P}<0.001)$ and artificial $(\mathrm{F}=43.29 ; \mathrm{P}<0.001)$ substrata. Mean abundance of ciliates $\left(25.4 \times 10^{2}\right.$ cells $\left.\mathrm{m}^{-2}\right)$ on artificial substrata was significantly higher (ANOVA; $\mathrm{F}=16.13$; $\mathrm{P}<0.001)$ than on natural substrata $\left(20.4 \times 10^{2}\right.$ cells $\left.\mathrm{m}^{-2}\right)$ (Fig. 4 A,B). Ciliate abundance was characterized by spring-autumn maxima on the artificial substrata, whereas on the natural substrata, abundance peaked in spring, summer, and late autumn. The highest abundances of ciliate communities on artificial substrata were noted in May and October with dominance by the bacterivorous Chilodonella uncinata, Cinetochilum margaritaceum and mixotrophic Coleps hirtus. On the reed stems, maxima were noted in May, July and October with the dominance

Tab. 1. Seasonal changes of physical and chemical parameters of water in lake Syczyńskie in 2007 (mean values for studied months).

\begin{tabular}{|c|c|c|c|c|c|c|c|}
\hline & May & Jun & Jul & Aug & Sep & Oct & Nov \\
\hline Temperature $\left({ }^{\circ} \mathrm{C}\right)$ & 14.2 & 25.5 & 22.1 & 21.4 & 16.8 & 8.5 & 6.4 \\
\hline Secchi disc depth (m) & 0.72 & 0.80 & 0.40 & 0.30 & 0.37 & 0.55 & 0.27 \\
\hline Conductivity $\left(\mu \mathrm{S} \mathrm{cm}^{-1}\right)$ & 563 & 502 & 323 & 341 & 477 & 480 & 437 \\
\hline Dissolved oxygen $\left(\mu \mathrm{g} \mathrm{L}^{-1}\right)$ & 9.2 & 9.9 & 12.0 & 13.2 & 9.1 & 9.9 & 10.6 \\
\hline $\mathrm{N}-\mathrm{NH}_{4}\left(\mu \mathrm{g} \mathrm{L}^{-1}\right)$ & 166 & 248 & 485 & 223 & 531 & 100 & 900 \\
\hline $\mathrm{N}-\mathrm{NO}_{3}\left(\mu \mathrm{g} \mathrm{L}^{-1}\right)$ & 36 & 90 & 45 & 57 & 166 & 98 & 112 \\
\hline $\mathrm{TP}\left(\mu \mathrm{g} \mathrm{L}^{-1}\right)$ & 168 & 222 & 321 & 92 & 252 & 131 & 76 \\
\hline $\mathrm{P}^{-} \mathrm{PO}_{4}\left(\mu \mathrm{g} \mathrm{L}^{-1}\right)$ & 47 & 172 & 28 & 36 & 186 & 24 & 34 \\
\hline Planktonic chlorophyll- $a\left(\mu \mathrm{g} \mathrm{L}^{-1}\right)$ & 11.90 & 21.18 & 24.40 & 30.46 & 29.99 & 40.94 & 24.28 \\
\hline TOC $\left(\mu \mathrm{g} \mathrm{L}^{-1}\right)$ & 7.7 & 6.4 & 7.1 & 6.6 & 6.4 & 7.0 & 7.4 \\
\hline
\end{tabular}


of Chilodonella uncinata, Amphileptus pleurosigma and Stylonychia mytilus-complex.

\section{Metazoa}

Rotifer (Bdelloidae, Lecane, Keratella) abundances were significantly higher (ANOVA; $\mathrm{F}=57.27 ; \mathrm{P}<0.001$ ) on the natural substrata (mean $4.3 \times 10^{2}$ ind. $\mathrm{m}^{-2}$ ) than on artificial ones (mean $3.7 \times 10^{2}$ ind. $\mathrm{m}^{-2}$ ). Similarly to rotifers, mean abundances of cladocerans, were significantly higher (ANOVA; $\mathrm{F}=28.84 ; \mathrm{P}<0.001$ ) on the natural substrata $\left(6.4 \times 10^{2}\right.$ ind. $\left.\mathrm{m}^{-2}\right)$. Copepods were never found on the artificial substrata (Fig. 5B). On both substrata, during the whole study period, rotifers were significantly more abundant than cladocerans and copepods (Fig. 5 A,B). On natural substrata, small metazoan were most abundant in spring, whereas on artificial substrata in autumn.

\section{Chironomids}

Macroinvertebrates on natural and artificial substrata were represented by larvae of Chironomidae (Fig. 6 A,B). Densities of midges showed significant differences among months on natural (ANOVA; $\mathrm{F}=22.54 ; \mathrm{P}<0.001$ ) and artificial substrata (ANOVA; $\mathrm{F}=10.62 ; \mathrm{P}<0.001$ ). Total abundances of chironomids were significantly higher (ANOVA; $\mathrm{F}=18.13 ; \mathrm{P}=0.017$ ) on natural substrata. On both substrata six chironomids taxa, were observed with varying proportions during the season (Fig. 6 A,B). The highest densities of chironomids on natural substrata were observed in May (5892 ind. $\mathrm{m}^{-2}$ ) and the lowest in September (1744 ind. $\mathrm{m}^{-2}$ ). In May, Cricotopus sp. (gr. sylvestris) larvae were dominant, while in September the larvae of Glyptotendipes sp. were the most abundant. On artificial substrata, the highest density of midges was ob- served in May (3154 ind. $\mathrm{m}^{-2}$ ) and the lowest in July (1100 ind. $\mathrm{m}^{-2}$ ). Cricotopus sp. (gr. sylvestris) larvae were the most abundant in May, while in July larvae of Psectrocladius sp. (gr. sordidellus) became dominant.

Relations between periphytic communities and environmental variables

PCA axis $1(\lambda=0.279)$ and axis $2(\lambda=0.166)$ explained $44.5 \%$ of the total variance in periphyton composition. The first two axes showed a clear separation of studied periphyton communities (Fig. 6A) and both studied substrata (Fig. 7B). The abundances of periphytic algae (cyanophytes, diatoms, chlorophytes) were most strongly correlated with the main direction of variation (axis 1), with samples collected on natural substrata (common reed) (Fig. 7A). Axis 2 was the most strongly correlated with abundance of chironomids. The density of larvae increased toward natural substrates and appeared to be closely related with season (the larvae show higher abundances in summer) (Fig. 7B). Axis 2 appeared to separate periphyton samples collected from natural and artificial substrata.

RDA performed in order to specify the direct relationships between abundances of taxonomic groups of periphyton and environmental variables; showed evident differences between studied substrata. On natural substrata all variables together explained $55.7 \%$ of total variance. However, variables that significantly $(\mathrm{P}<0.05$, Monte Carlo permutation test) explained the variance in periphyton communities abundance on natural substrata included temperature $(\lambda=0.17 ; \mathrm{F}=10.48 ; \mathrm{P}=0.004)$, Secchi disc depth $(\lambda=0.04 ; \mathrm{F}=2.72 ; \mathrm{P}=0.049), \mathrm{N}-\mathrm{NO}_{3}(\lambda=0.19 ; \mathrm{F}=9.31$; $\mathrm{P}=0.002)$ and TOC $(\lambda=0.04 ; \mathrm{F}=2.47 ; \mathrm{P}=0.027)$. In the RDA biplot for periphyton taxonomic groups (Fig. 8A), axis 1 appeared to separate the different components of periphyton food web; microorganisms (periphytic algae and cili-
A) Natural substrata

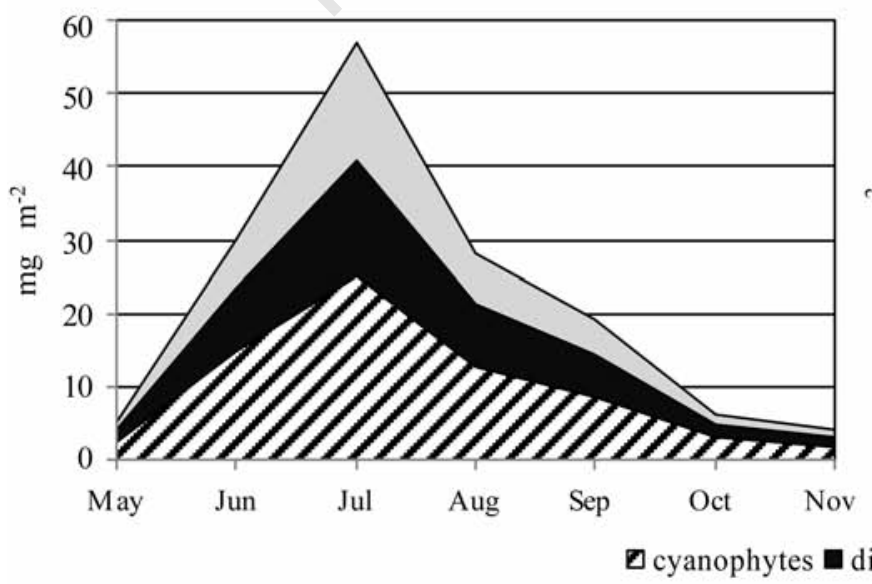

B) Artificial substrata

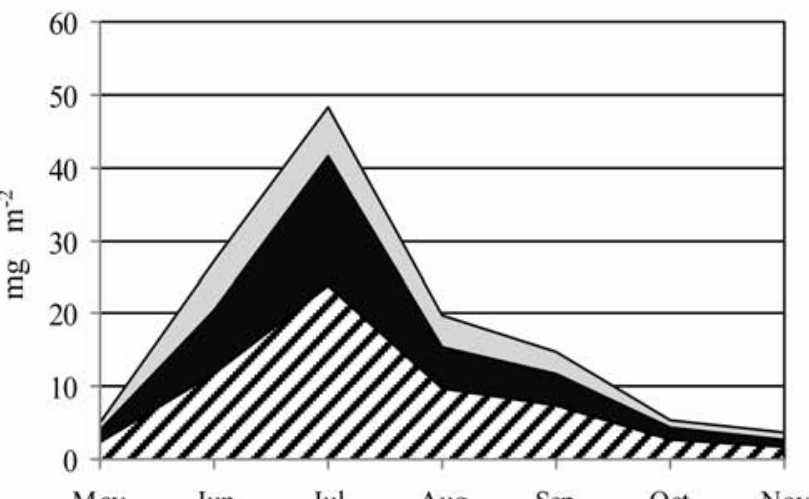

diatoms $\square$ chlorophytes

Fig. 3. Relative proportions $\left(\mathrm{mg} \mathrm{m}^{-2}\right)$ of cyanophyte, diatoms and chlorophytes in total biomass of periphytic algae in studied months on A) natural substrata (reed) and B) artificial substrata (bamboo). 
ates) are separated from their main consumers (metazoa and chironomids). The RDA biplot for sites shows the direct effect of season on periphyton community on natural substrata (Fig. 8B). On the biplot it can be observed that samples collected in spring (May, first group) are separated from those collected in summer (June, July and August, second group) and autumn (September, October and November, third group). RDA for artificial substrata showed that all variables explained $37 \%$ of the total variance. Monte Carlo permutation test showed the significance of three variables: temperature $(\lambda=0.12 ; \mathrm{F}=5.62 ; \mathrm{P}=0.008)$, $\mathrm{P}_{-} \mathrm{PO}_{4}(\lambda=0.01 ; \mathrm{F}=5.50 ; \mathrm{P}=0.006)$ and TOC $(\lambda=0.06$; $\mathrm{F}=2.98 ; \mathrm{P}=0.048)$. On the RDA biplot for periphyton communities, axis 1 and 2 separate periphyton communities into three groups: i) algae; ii) ciliates with metazoa; and iii) chironomids (Fig. 9A). The RDA biplot for substrates, similarly to natural substrata, showed evident differences between studied months (Fig. 9B), and separating collected data into three groups; first group included samples collected in July and it may correspond with abundances of periphytic algae (Fig. 9A); second group included samples collected in June, August and September; third group included samples collected in May, October and November and this group may correspond with abundances of ciliates and metazoa (Fig. 9A).

\section{Relationships among food web components}

Generally, the biomass of algae was negatively correlated with the abundance of ciliates, small metazoa and chironomids (from $r=-0.45, \mathrm{P} \leq 0.05$ to $r=-0.77, \mathrm{P} \leq 0.01$ ).
However, the number of significant correlations between the main group of organisms forming the periphytic food webs was differed between substrata. On artificial substrata the relations among food web components were stronger. Biomass of cyanophyte, diatoms and chlorophytes correlated negatively with the density of protists $(r=-0.76$, $\mathrm{P} \leq 0.01)$, copepods ( $r=-0.64, \mathrm{P} \leq 0.01)$ and/or chironomids $(r=-0.43, \mathrm{P} \leq 0.05)$. The abundance of protists and small metazoa correlated positively with the density of macroinvertebrates (from $r=0.48$ to $r=0.55, \mathrm{P} \leq 0.05$ ). On natural substrata, there was a significant and positive correlation between crustaceans density and small-sized rotifers $(r=0.73, \mathrm{P} \leq 0.01)$. Chironomid density correlated positively with the abundance of copepods $(r=0.69, \mathrm{P} \leq 0.01)$ and negatively with the biomass of cyanophyte $(r=-0.43, \mathrm{P} \leq 0.05)$.

\section{DISCUSSION}

The results confirmed that under hypertrophic conditions, artificial substrata markedly increased the colonization area for periphyton communities. The introduction of bamboo substrates lead to a rapid development of different groups of periphytic organisms. In general, the taxonomic composition of periphytic algae, ciliates, metazoan and chironomids was similar on artificial substrata and common reed, but their total densities on bamboo substrates were usually lower than on plants. Similar results were reported in the studies concerning colonization process on natural and artificial substrata by ciliates (Chadwick and Canton, 1983; Boothroyd and Dickie, 1989), metazoan (Pejler and Berzips, 1989; Duggan,

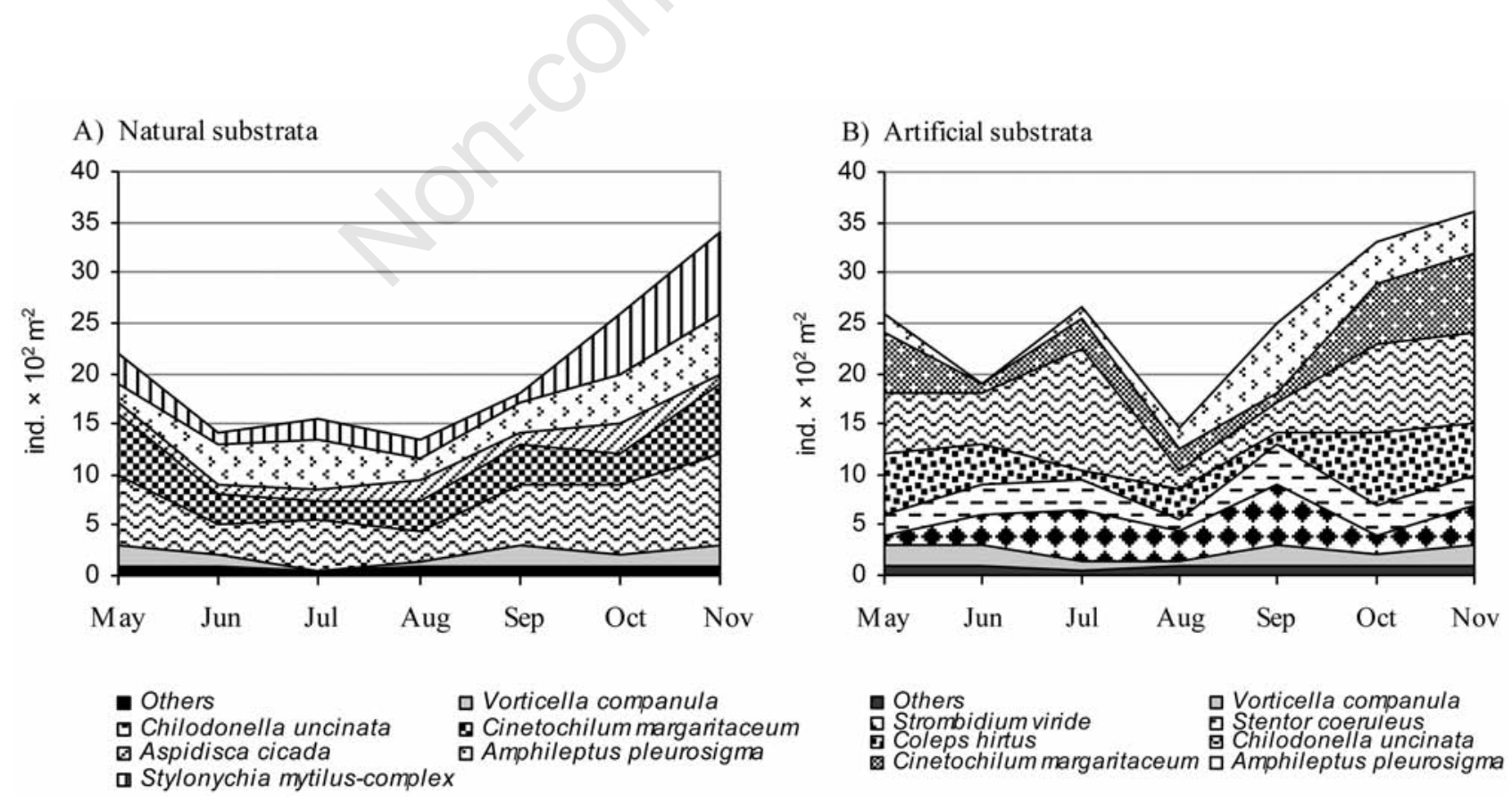

Fig. 4. Relative abundances (ind. $10^{2} \mathrm{~m}^{-2}$ ) of ciliates taxa in total density of periphytic ciliates in studied months on A) natural substrata (reed) and B) artificial substrata (bamboo). 
2001) and chironomids (Wotton et al., 1992; Francis and Kane, 1995). The increased growth of periphytic algae on reed stems, compared to artificial bamboo substrata, may be due to the nutrient exchange between the living reed and periphyton. This statement supports the results observed by Ács and Buczko (1994) and Ács et al. (2003) who reported the stimulation of algae growth through the secretion of nutrients from macrophytes.

The structure of periphyton communities on natural and artificial substrata was related to the high productivity of the studied lake ecosystem. Algae on both substrates were dominated by filamentous cyanophyte. These algae usually constitute an important component of periphyton assemblage at high phosphorous levels (McCormick and O’Dell, 1996; Gaiser et al., 2005). High concentrations of phosphorous resulted in high biomass of periphytic algae. On natural and artificial substrata algae biomass in most studied months exceeded $10 \mathrm{mg} \mathrm{cm}^{-2}$. This value is typical for hypertrophic lakes (Hitzfeld et al., 2000). The observation is in agreement with nutrient loading studies by McCormick et al. (2002) and Gaiser et al. (2006), which have shown that periphyton rapidly accumulates phosphorous in proportion to the loading rate and usually the increase in phosphorous concentration is accompanied by high periphyton biomass. The biomass of periphytic algae observed during the study showed a negative rela-

\section{A) Natural substrata}

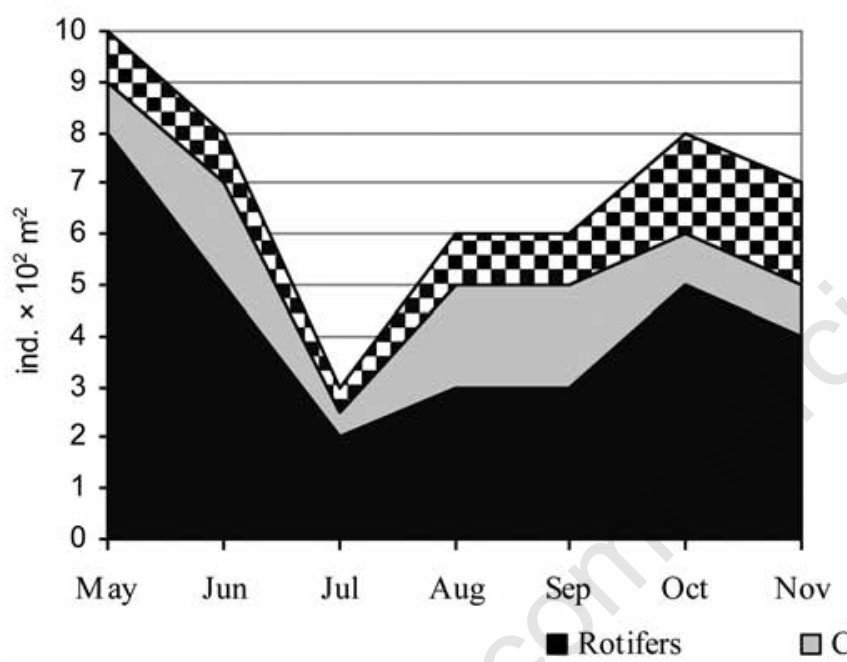

B) Artificial substrata

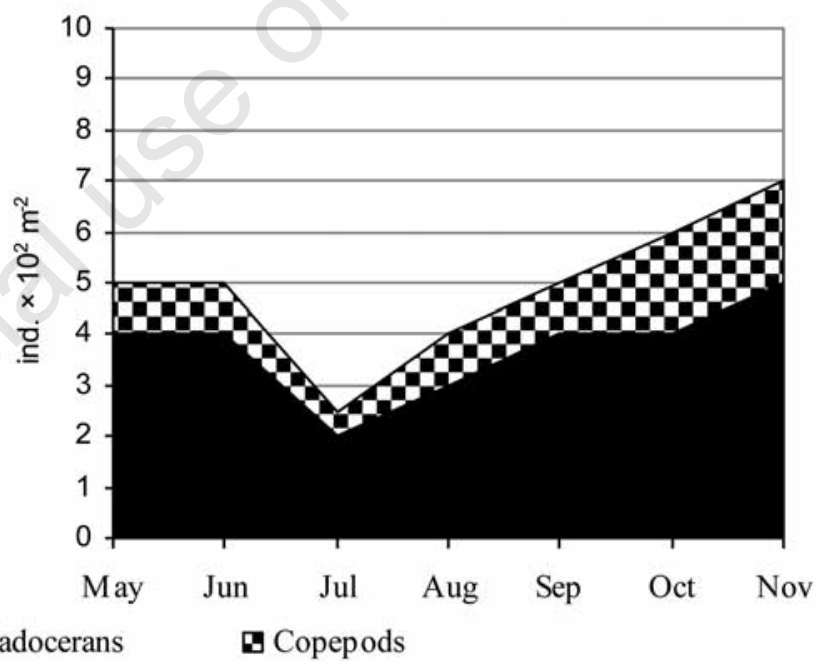

Fig. 5. Relative abundances (ind. $10^{2} \mathrm{~m}^{-2}$ ) of rotifers, cladocerans and copepods in total density of metazoa in studied months on A) natural substrata (reed) and B) artificial substrata (bamboo).

A) Natural substrata

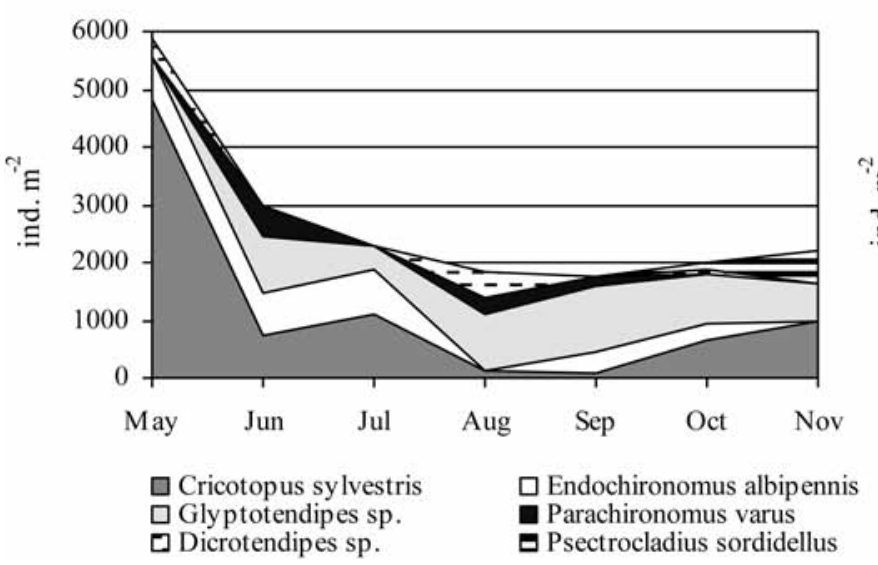

B) Artificial substrata

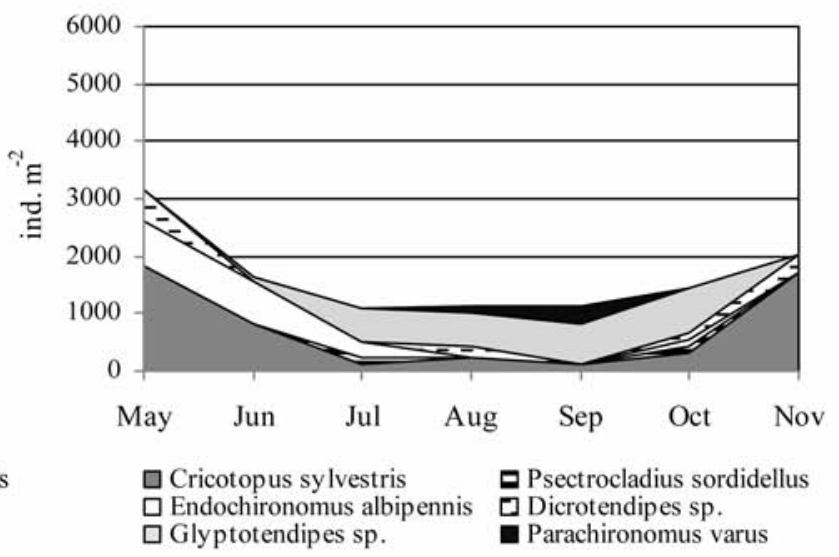

Fig. 6. Relative abundances (ind. $\mathrm{m}^{-2}$ ) of chironomids taxa in total density of periphytic chironomids in studied months on A) natural substrata (reed) and B) artificial substrata (bamboo). 

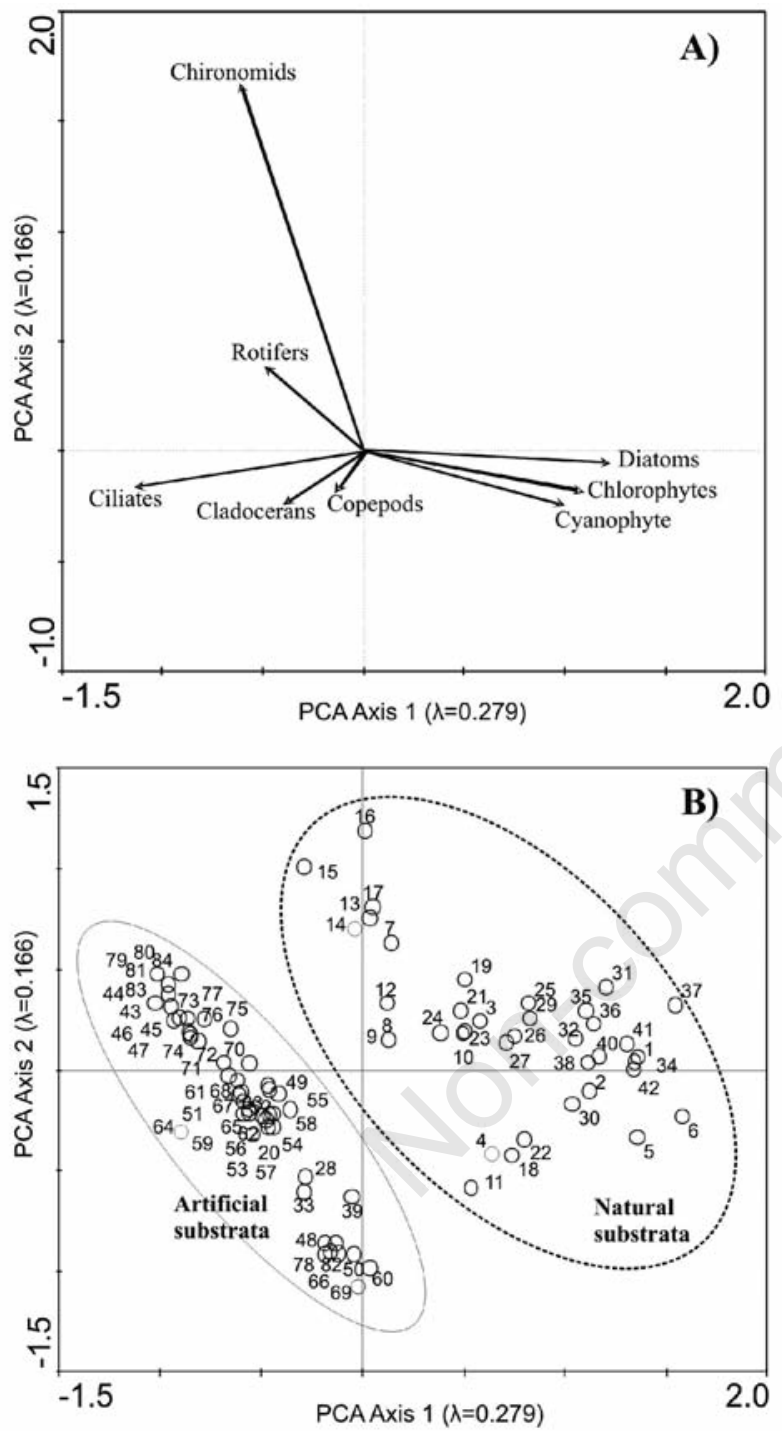

Fig. 7. Principal Components Analysis (PCA) biplots for axes 1 and 2 showing: A) periphytic communities, B) study substrata. Axes are derived from the variation in the taxonomic data -matrix. Samples collected in studied months are marked with an Arabic numeral: 1-6 May; 7-12 June; 13-18 July; 19-24 August; 25-30 September; 31-36 October; 37-42 November.
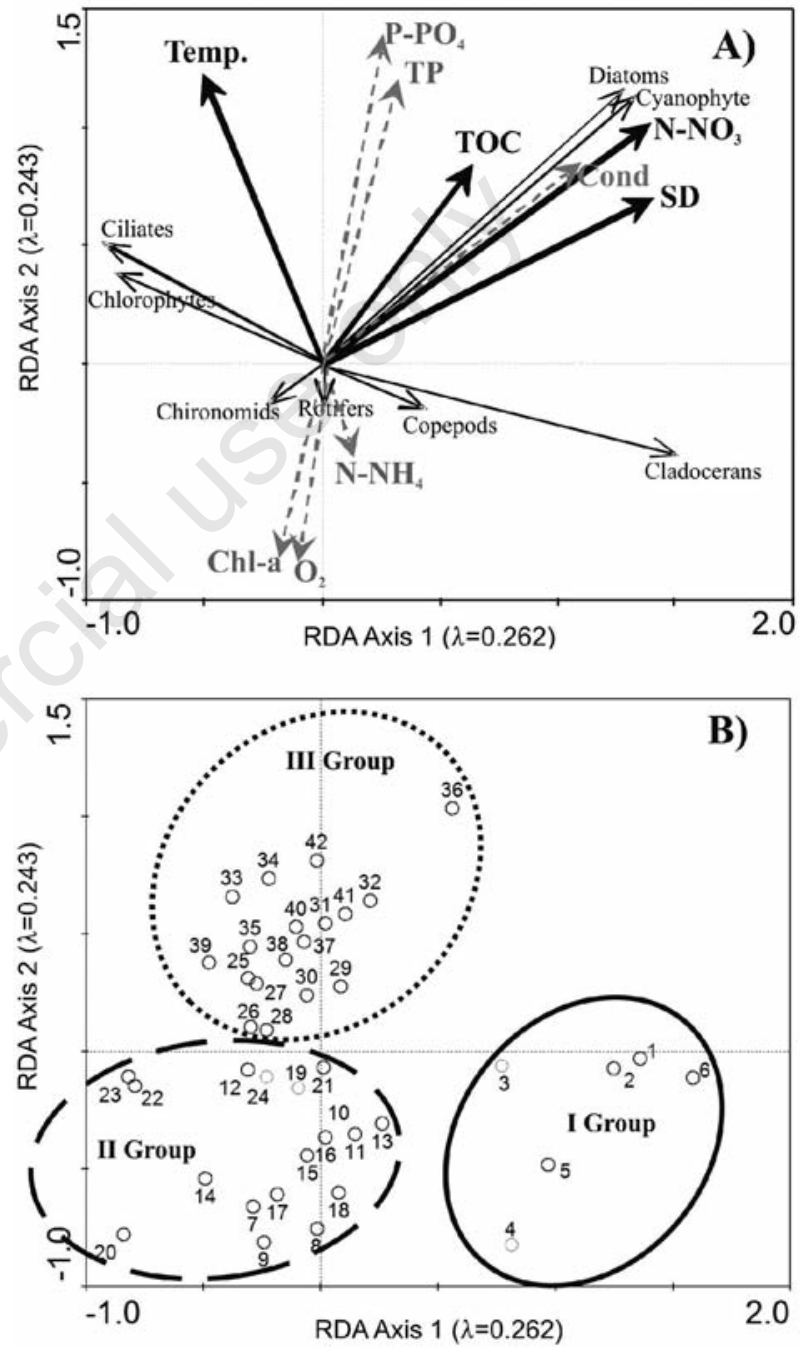

Fig. 8. Redundancy Analysis (RDA) biplots for natural substrata showing: A) periphytic communities and environmental variables, B) samples collected in studied months and environmental variables. Solid arrows indicate significant variables based on Monte Carlo permutation test $(\mathrm{P}<0.05)$. Samples collected in studied months are marked with an Arabic numeral: 1-6 May; 7-12 June; 13-18 July; 19-24 August; 25-30 September; 31-36 October; 37-42 November. SD, Secchi disc depth; Temp, water temperature; Cond, conductivity; $\mathrm{O}_{2}$, dissolved oxygen; Chl- $a$, chlorophyll- $a$; $\mathrm{N}-\mathrm{NH}_{4}$, ammonium nitrogen; $\mathrm{N}-\mathrm{NO}_{3}$, nitrate nitrogen; TP, total phosphorous; $\mathrm{P}_{-} \mathrm{PO}_{4}$, dissolved orthophosphates; TOC, total organic carbon. 
tion with Secchi disc visibility; this may confirm the results recorded by Havens et al. (1996), who found that the trend of the periphytic algae amount is opposite to that of water transparency.

Periphytic algae community is structured by grazing (Jernakoff and Nielsen, 1997). According to Jones and Sayer (2003) and Danger et al. (2008), macroinvertebrates are known to prey intensively on algae and can easily affect their biomass. Most invertebrate grazers (cladocerans, copepods, chironomids) are scrapers or filter-feeders (Hart and Lovvorn, 2000). In lake Syczyńskie, which was the object of the study, the highest densities of chironomids on both natural and artificial substrata were observed in May when the biomass of periphytic algae was low. This observation may suggest high grazing pressure of midges on algae. Periphytic algae are regarded as an important source of food for chironomid larvae (Botts and Cowell, 1992; Pinder, 1992; Tall et al., 2006). The larvae utilized as food the most abundant algae taxa (Botts, 1993). In lake Syczyńskie algal community was dominated by cyanophyte. These algae may constitute the important food source for grazing larvae. Studies of Dvorak (1996) on the chironomids and their food resources on Typha angustifolia and Phragmites australis showed that filamentous cyanophyte prevailed Endochironomus albipennis diet, making above $90 \%$ of its total food. In the investigated lake, the number of ciliates was significantly affected by the concentration of chlorophyll- $a$. Generally, the high content of chlorophyll- $a$ during the summer period was accompanied by an increase in the number of species belonging to the omnivorous Cyrtophorida and algivorous Oligotrichida. It is probable that this is a result of advantageous feeding conditions. A significant influence of chlorophyll- $a$ on the number of ciliates is confirmed by the studies of Beaver and Crisman (1990) in lakes of different trophic status.

As it was reported by many researchers, food availability has the primary influence on grazer community (Tokeshi, 1986; Francis and Kane, 1995; Gresens, 1997). The larvae of chironomids have been described as being able to grow on diverse food sources, including algae, metazoan or ciliates (Berg, 1995; Tarkowska-Kukuryk and Mieczan, 2008; Maasri et al., 2010). In the present study, the abundance of chironomids was negatively correlated with the biomass of cyanophyte, diatoms and concentrations of chlorophyll- $a$. The highest abundances of ciliate and metazoa were noted in autumn when predation pressure was low, whereas their population was strongly reduced in summer at high abundance of epiphytic chironomids. A strong decline of ciliate populations in early summer was reported as a result of predation by chironomid larvae of Cricotopus sylvestris group (Tarkowska-Kukuryk and Mieczan, 2008). The growth in the abundance of small metazoa on Phragmites australis may result in profitable feeding conditions. In lake Syczyńskie, mostly filamentous algae appeared on both natural and artificial substrata. Studies by Ács et al. (2003) and Haglund and Hillebrand (2005) point to a distinct increase in the abundance of bacteria in the periphyton of the dominant filamentous algae. This may result in profitable feeding conditions for small metazoa (mostly rotifers) which usually colonize microsites formed in the mats of filamentous algae.
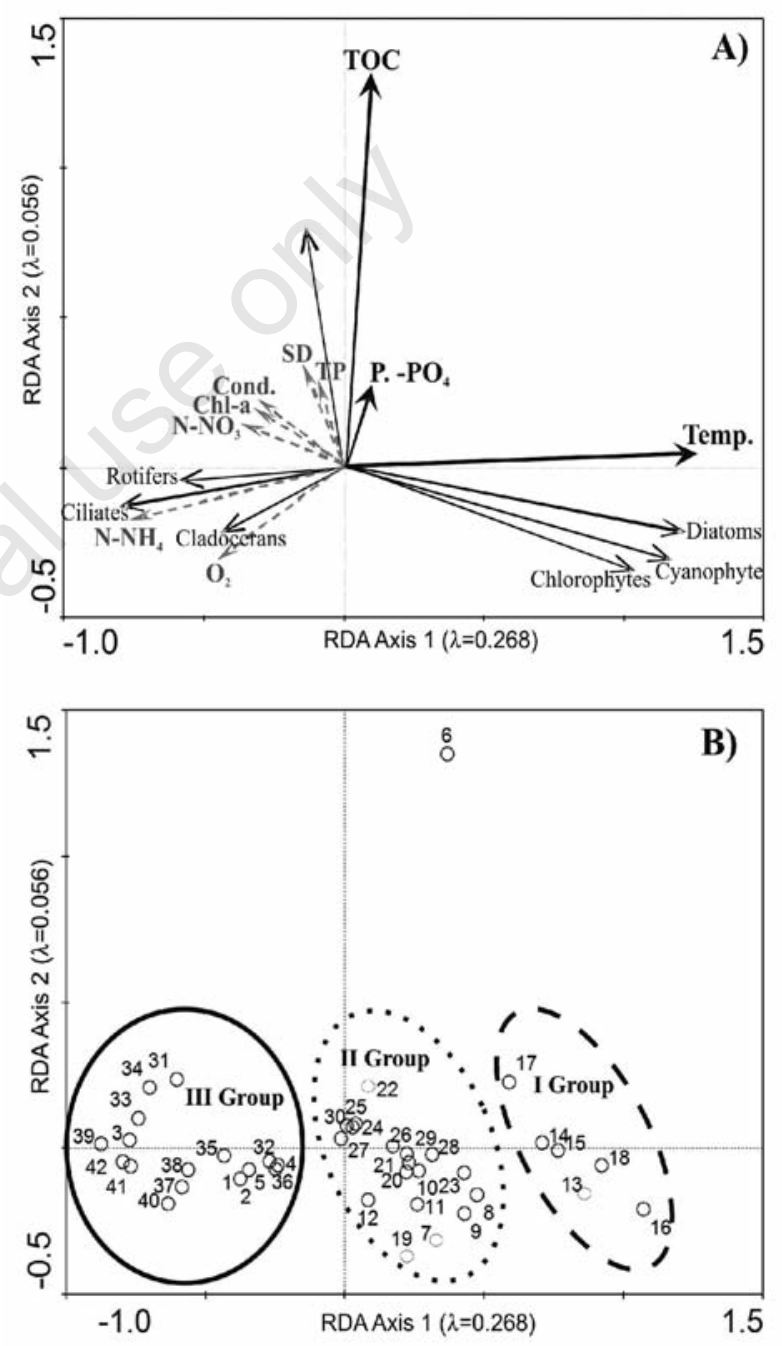

Fig. 9. Redundancy Analysis (RDA) biplots for artificial substrata showing: A) periphytic communities and environmental variables, B) samples collected in studied months and environmental variables. Solid arrows indicate significant variables based on Monte Carlo permutation test $(\mathrm{P}<0.05)$. Samples collected in studied months are marked with an Arabic numeral: 1-6 May; 7-12 June; 13-18 July; 19-24 August; 25-30 September; 31-36 October; 3742 November. SD, Secchi disc depth; Temp, water temperature; Cond, conductivity; $\mathrm{O}_{2}$, dissolved oxygen; Chl- $a$, chlorophyll$a$; $\mathrm{N}_{-} \mathrm{NH}_{4}$, ammonium nitrogen; $\mathrm{N}-\mathrm{NO}_{3}$, nitrate nitrogen; TP, total phosphorous; $\mathrm{P}_{-} \mathrm{PO}_{4}$, dissolved orthophosphates; TOC, total organic carbon. 


\section{CONCLUSIONS}

The abundances of periphyton communities (algae, ciliates, metazoan, chironomids) in shallow hypertrophic lake were closely related to substrate and season. Periphyton communities showed the strongest relations to five environmental variables (temperature, Secchi disc depth, $\left.\mathrm{N}-\mathrm{NO}_{3}, \mathrm{P}_{-} \mathrm{PO}_{4}, \mathrm{TOC}\right)$. The results suggest that under hypertrophic conditions, where soft vegetation is thick or absent, artificial substrates may spread colonization area and enhance the growth of different group of organisms. On artificial (bamboo) substrata interactions between components of periphytic food web are stronger in compare to natural plants. Moreover, high negative values of Pearson's correlation coefficient between periphytic algae and herbivores (ciliates, metazoan, chironomids) observed on artificial substrata, indicate intensive grazing pressure on algae.

\section{REFERENCES}

Ács E, Buczkó K,1994. Algological and bacteriological investigations on reed periphyton in Lake Velencei, Hungary, p. 1-10. In: D.G. Mann and M.J. Sullivan (eds.), Proc. $13^{\text {th }}$ Int. Diatom Symp. Biopress Limited, Bristol, UK.

Ács E, Borsodi AK, Makk J, Molnar P, Mozes A, Rusznyak A, Reskone MN, Kiss KT, 2003. Algological and bacteriological investigations on reed periphyton in Lake Velencei, Hungary. Hydrobiologia 506-509:549-557.

Albay M, Akcaalan R, 2003. Comparative study of periphyton colonization on common reed (Phragmites australis) and artificial substrate in a shallow lake, Manyas, Turkey. Hydrobiologia 506-509:531-540.

Atilla N, Fleeger JW, Finelli CM, 2005. Effects of habitat complexity and hydrodynamics on the abundance and diversity of small invertebrates colonizing artificial substrates. J. Mar. Res. 63:1151-1172.

Augustin H, Foissner W, Adam H, 1984. An improved pyridiniated silver carbonate method which need few specimens and yields permanent slides of impregnation ciliates (Protozoa, Ciliophora). Mikroskopie 41:134-137.

Azim ME, Wahab MA, Verdegem MCJ, van Dam AA, van Rooij JM, Beveridge MCM, 2002. The effect of artificial substrates on freshwater pond productivity and water quality and the implications periphyton-based aquaculture. Aquat. Living Resour. 15:231-241.

Beaver JR, Crisman LT, 1990. Seasonality of planktonic ciliated protozoa in 20 subtropical Florida lakes of varying trophic state. Hydrobiologia 190:127-135.

Benoit HP, Post JR, Parkinson EA, Johnston NT, 1998. Colonization by lentic macroinvertebrates: evaluating colonization processes using artificial substrates and appraising applicability of the technique. Can. J. Fish. Aquat. Sci. 55:2425-2435.

Berg MB, 1995. Larval food and feeding behavior, p. 136-168. In: P.D. Armitage, P.S. Cranston and L.C.V. Pinder (eds.), The Chironomidae. The biology and ecology of non-bitting midges. Chapman \& Hall, London.

Boothroyd IKG, Dickie BN, 1989. Macroinvertebrates coloniza- tion of perspex artificial substrates for use in biomonitoring studies. Z. J. Mar. Freshwater Res. 23:467-478.

Botts PS, 1993. The impact of small chironomids grazers on epiphytic algal abundance and dispersion. Freshwat. Biol. 30:25-33.

Botts PS, Cowell BC, 1992. Feeding electivity of two epiphytic chironomids in a subtropical lake. Oecologia 89:331-337.

Chadwick JW, Canton SP, 1983. Comparison of multiplate and surber samples in Colorado Mountain stream. J. Freshwat. Ecol. 2:281-292.

Chaloner DT, Wotton RS, 1996. Substratum preferences by larvae of three species of midge (Dipetra: Chironomidae). Hydrobiologia 339:93-99.

Danger M, Lacroix G, Oumarou C, Benest D, Merifuet J, 2008. Effect of food-web structure on periphyton stichiometry in eutrophic lakes: a mesocosm study. Freshwat. Biol. 53:20892100.

Danilov RA, Ekelund NGA, 2001. Comparison of usefulness of three types of artificial substrata (glass, wood and plastic) when studying settlement patterns of periphyton in lakes of different trophic status. J. Microbiol. Meth. 45:161-170.

Declerck S, Vandekerkhove J, Johansson L, Muylaert K, CondePorcuna JM, van der Gucht K, 2005. Multi-group biodiversity in shallow lakes along gradients of phosphorus and water plant cover. Ecology 86:1905-1915.

Duggan IC, 2001. The ecology of periphytic rotifers. Hydrobiologia 446/447:139-148.

Dvorak J, 1996. An example of relationships between macrophytes, macroinvertebrates and their food resources in a shallow eutrophic lake. Hydrobiologia 339:27-36.

Fairchild GW, Everett AC, 1988. Effects of nutrient (N P C) enrichment upon periphyton standing crop, species composition and primary production in an oligotrophic softwater lake. Freshwat. Biol. 19:57-70.

Francis DR, Kane TC, 1995. Effect of substrate on colonization of experimental ponds by Chironomidae (Diptera). J. Freshwat. Ecol. 10:57-63.

Foissner W, Berger H, 1996. A user-friendly guide to the ciliates (Protozoa, Ciliophora) commonly used by hydrobiologists as bioindicators in rivers, lakes and waste waters, with notes on their ecology. Freshwat. Biol. 35:375-470.

Foissner W, Berger H, Schaumburg J, 1999. Identification and Ecology of Limnetic Plankton Ciliates. Informationsberichte des Bayer, Landesamtes für Wasserwirtschaft, München: 777 pp.

Gaiser EE, Texler JC, Richards JH, Childers DL, Lee D, Edwards AL, Scinto LJ, Jayachandaran K, Noe GB, Jones RD, 2005. Cascading ecological effects of low-level phosphorous enrichment in the Florida Everglades. J. Environ. Qual. 34:717-723.

Gaiser EE, Childers DL, Jones RD, Richards JH, Scinto LJ, Texler JC, 2006. Periphyton responses to eutrophication in the Florida Everglades: cross-system patterns of structural and compositional change. Limnol. Oceanogr. 51:617-630.

Golterman HL, 1969. Methods for chemical analysis of freshwaters. IBP Handbook No. 8. Blackwell Scientific Publications, Oxford, Edinburgh: 172 pp.

Gonzalez-Sagrario MA, Jeppesen E, Goma J, Søndergaard M, Jensen JP, Lauridsen T, 2005. Does high nitrogen loading prevent clear-water conditions in shallow lakes at moder- 
ately high phosphorus concentrations? Freshwat. Biol. 50:27-41.

Gresens S, 1997. Interactive effect of diet and thermal regime on growth of the midge Pseudochironomus richardsoni Malloch. Freshwat. Biol. 38:365-373.

Gross EM, Meyer H, Schilling G, 1996. Release and ecological impact of algicidal hydrolysable polyphenols in Myriophyllum spicatum. Phytochemistry 41:133-138.

Haglund AL, Hillebrand H, 2005. The effect of grazing and nutrient supply on periphyton associated bacteria. FEMS Microbiol. Ecol. 52:31-41.

Hart EA, Lovvorn JR, 2000. Vegetation dynamics and primary production in saline, lacustrine wetlands of a Rocky Mountain basin. Aquat. Bot. 66:21-39.

Havens KE, East TL, Meeker RH, Davis WP, Steinman AD, 1996. Phytoplankton and periphyton responses in situ experimental nutrient enrichment in a shallow subtropical lake. J. Plankton Res. 18:551-566.

Henglong X, Gi-Sik M, Joong-Ki Ch, Se-Joo K, Jae-Ho J, ByungJin L, 2009. Periphytic ciliate colonization of an artificial substrate in Korean coastal waters. Protistology 6:55-65.

Hermanowicz W, Dojlido J, Dożańska W, Koziorowski B, Zerbe J, 1999. Fizyczno-chemiczne badanie wody i ścieków. Arkady, Warszawa: 846 pp.

Hillebrand H, Sommer U, 2000. Effect of continuous nutrient enrichment on microalgae colonizing hard substrates. Hydrobiologia 426:185-192.

Hitzfeld BC, Höger SJ, Dietrech DR, 2000. Cyanobacterial toxins: removal during drinking water treatment, and human risk assessment. Environ. Health Perspect. 108:113-122.

Jernakoff P, Nielsen J, 1997. The relative importance of amphipod and gastropod grazers in Posidonia sinuosa meadows. Aquat. Bot. 56:183-202.

Jones JI, Moss B, Young JO, 1998. The interactions between periphyton, non-molluscan invertebrates and fish in standing freshwaters, p. 69-90. In: E. Jeppesen, Ma. Søndergaard, Mo. Søndergaard and K. Christophersen (eds.), The structuring role of submerged macrophytes in lakes. SpringerVerlag, New York.

Jones JI, Moss B, Eaton JW, Young JO, 2000. Do submerged aquatic plants influence periphyton community composition for the benefit of invertebrate mutualists? Freshwat. Biol. 43:591-604.

Jones JI, Sayer CD, 2003. Does the fish-invertebrate-periphyton cascade precipitate plant loss in shallow lakes? Ecology $84: 2155-2167$

Jongman RHG, ter Braak CJF, van Tongeren DFR, 1987. Data analysis in community and landscape ecology. Pudoc, Wageningen: $299 \mathrm{pp}$.

Kahlert M, Pettersson K, 2002. The impact of substrate and lake trophy on the biomass and nutrient status of benthic algae. Hydrobiologia 489:161-169.

Kaur P, Mehra NK, 1998. Laboratory studies on colonization and succession patterns on periphytic microbiota on artificial and natural substrates. Verh. Internat. Verein. Limnol. 26:1614-1620.

Kiss MK, Lakatos G, Borcis G, Gido Z, Deak C, 2003. Littoral macrophyte-periphyton complexes in two Hungarian shallow waters. Hydrobiologia 506-509:541-548.

Kornijów R, Kairesalo T, 1994. A simple apparatus for sampling epiphytic communities associated with emergent macrophytes. Hydrobiologia 294:141-143.

Kralj K, Plenkovic-Moraj A, Gligora M, Primc-Habdija B, Sipos L, 2006. Structure of periphytic community on artificial substrata: influence of depth, slide orientation and colonization time in karstic Lake Visovacko, Croatia. Hydrobiologia 560:249-258.

Lane ChM, Taffs KH, Corfield JL, 2003. A comparison of diatom community structure on natural and artificial substrata. Hydrobiologia 493:65-79.

Lepš J, Šmilauer P, 2003. Multivariate Analysis of Ecological Data using CANOCO. Cambridge University Press: 269 pp.

Liboriussen L, Jeppesen E, Bramm ME, Lassen MF, 2005. Periphyton-macroinvertabrate interactions in light and fish manipulated enclosures in a clear and a turbid shallow lake. Aquat. Ecol. 39:23-39.

Maasri A, Fayolle S, Franquet E, 2010. Algal foraging by a rheophilic chironomid (Eukiefferiella claripennis Lundbeck) extensively encountered in high nutrient enriched streams. Fundam. Appl. Limnol. 177:151-159.

McCormick PV, O’Dell MB, 1996. Quantifying periphyton responses to phosphorous enrichment in the Florida Everglades: a synoptic-experimental approach. J. North. Am. Benth. Soc. 15:450-468.

McCormick PV, Newman S, Miao S, Gawlik DE, Marley D, Reddy KR, Fontaine TD, 2002. Effects of anthropogenic phosphorous inputs on the Everglades, p. 83-126. In: Porter J.W. and K.G. Porter (eds). The Everglades, Florida Bay and coral reefs of the Florida Keys: An Ecosystem Sourcebook. CRC Press, Boca Raton.

Mieczan T, 2006. Studies on the colonization and succession patterns of periphytic ciliates communities on natural and artificial substrata in two lakes of different trophic status. Polish J. Environ. Stud. 15/5d: 557-561.

Moeller RE, Burkholder JM, Wetzel RG, 1988. Significance of sedimentary phosphorous to a rooted submersed macrophyte (Najas flexilis (Willd.) Rostk. And Schmidt) and its algal epiphytes. Aquat. Bot. 32:261-281.

Moschini-Carlos V, Henry R, Pompeo MLM, 2000. Seasonal variation of biomass and productivity of the periphytic community on artificial substrata in the Jurumirim Reservoir (São Paulo, Brazil). Hydrobiologia 434:35-40.

Pejler B, Berzins B, 1989. On choice of substrate and habitat in brachionid rotifers. Hydrobiologia 186/187:137-144.

Pinder LCV, 1992. Biology of epiphytic Chironomidae (Diptera: Nematocera) in chalk stream. Hydrobiologia 248:39-51.

Reid MA, J. Tibby JC, Penny D, Gell PA, 1995. The use of diatoms to assess past and present water quality. Aust. J. Ecol. 20:57-64.

Riber HH, Sorensen JP, Kowalczewski A, 1983. Exchange of phosphorous between water, macrophytes and epiphytic periphyton in the littoral of Mikołajskie Lake, Poland, p. 326343. In: R.G. Wetzel (ed.), Periphyton of freshwater ecosystems. Dr W. Junk Publishers, The Hague.

Rosemond AD, Mulholland P, Elwood JW, 1993. Top-down and bottom-up control of stream periphyton: effects of nutrients and herbivores. Ecology 74:1264-1280.

Rott E, 1981. Some results from phytoplankton counting intercalibrations. Schweiz Z. Hydrol. 43:34-62.

Sakuma M, Hanazato T, Saji A, Nakazato R, 2004. Migration 
from plant to plant: an important factor controlling densities of the epiphytic cladoceran Alona (Chydoridae, Anomopoda) on lake vegetation. Limnology 5:17-23.

Scheffer M, Hosper SH, Meijer ML, Moss B, Jeppesen E, 1993. Alternative equilibria in shallow lakes. Trends Ecol. Evolut. 8:275-279.

Tall L, Cattaneo A, Cloutier L, Dray S, Legendre P, 2006. Resource partitioning in a grazer guild feeding on a multilayer diatom mat. J. N. Am. Benthol. Soc. 25:800-810.

Taniguchi H, Nakano S, Tokeshi M, 2003. Influences of habitat complexity on the diversity and abundance of epiphytic invertebrates on plants. Freshwat. Biol. 48:718-728.

Tarkowska-Kukuryk M, Mieczan T, 2008. Diet composition of epiphytic chironomids of the Cricotopus sylvestris group (Diptera: Chironomidae) in a shallow hypertrophic lake. Aquat. Insect. 4:285-294.

ter Braak CJF, Šmilauer P, 2002. CANOCO Reference Manual and User's Guide to Canoco for Windows: Software for Canonical Community Ordination (version 4.5). Microcomputer Power (Ithaca, NY, USA): 500 pp.
Tokeshi M, 1986. Resource utilization, overlap and temporal community dynamics: a null model analysis of an epiphytic chironomids community. J. Anim. Ecol. 55:491-506.

van den Hoek C, Mann DG, Jahns HM, 1995. Algae. An introduction to phycology. Cambridge University Press, Cambridge: $623 \mathrm{pp}$.

Vermaat JE, 2005. Periphyton dynamics and influencing factors, p. 35-49. In: M.E. Azim, M.C.J. Verdegem, A.A. van Dam and M.C.M. Beveridge (eds.), Periphyton. Ecology, Exploitation and Management. CABI Publishing, London.

Wetzel RG, 1990. Land-water interfaces: metabolic and limnological regulators. Int. Ver. Theor. Angew. Limnol. 24:6-24.

Wiederholm T, 1983. Chironomidae of the Holarctic region. Keys and diagnoses. Part 1. Larvae. Entomologica Scandinavica. Supplement 19. Borgströms Tryckeri AB, Motala: $538 \mathrm{pp}$.

Wotton RS, Armitage PD, Aston K, Blackburn JH, Hamburger M, Woodward CA, 1992. Colonization and emergence of midges (Chironomidae: Diptera) in slow sand filter bed. Neth. J. Aquat. Ecol. 26:331-339. 